\title{
APPLICABILITY OF COLOURED TRAPS FOR THE MONITORING OF THE INVASIVE ZIGZAG ELM SAWFLY, APROCEROS LEUCOPODA (HYMENOPTERA: ARGIDAE)
}

\author{
Gábor Vétek ${ }^{1}$, Veronika Papp ${ }^{1}$, József Fail ${ }^{1}$, Márta Ladányi ${ }^{2}$ and Stephan M. Blank ${ }^{3}$ \\ ${ }^{1}$ Department of Entomology, Szent István University \\ H-1118 Budapest, Villányi út 29-43, Hungary; E-mails: Vetek.Gabor@kertk.szie.hu \\ veronika.papp11@gmail.com, Fail.Jozsef@kertk.szie.hu \\ ${ }^{2}$ Department of Biometrics and Agricultural Informatics, Szent István University \\ H-1118 Budapest, Villányi út 29-43, Hungary; E-mail: Ladanyi.Marta@kertk.szie.hu \\ ${ }^{3}$ Senckenberg Deutsches Entomologisches Institut \\ Eberswalder Str.90, 15374 Müncheberg, Germany; E-mail: Stephan.Blank@senckenberg.de
}

\begin{abstract}
Aproceros leucopoda (Hymenoptera: Argidae), native to East Asia, is an invasive pest of elms (Ulmus spp.) recently reported from several European countries. The identification of effective and practical tools suitable for detecting and monitoring the species has become necessary. As no trapping methods have been developed for A. leucopoda yet, in this study we compared white, yellow and fluorescent yellow sticky "cloak" traps for their applicability for catching adults. The experiment was carried out in a mixed forest plantation of black locust (Robinia pseudoacacia) and Siberian elm (Ulmus pumila), the latter infested heavily with A. leucopoda, in Hungary, 2012. Both the yellow and fluorescent yellow sticky "cloak" traps proved suitable for capturing high numbers of individuals of A. leucopoda, while the white traps caught significantly less adults. Trapping with the former coloured traps, completed with the inspection of host plants, may be recommended for the detection and monitoring of the pest.
\end{abstract}

Key words: Symphyta, alien species, Ulmus, trapping, signalisation.

\section{INTRODUCTION}

The zigzag elm sawfly, Aproceros leucopoda Takeuchi, 1939 (Hymenoptera: Argidae), native to East Asia, was identified as a new pest of elms ( $U l$ mus spp.) in Europe in 2003 (BLANK et al. 2010). Following the first discoveries of the pest in Poland, Hungary, Romania, Ukraine, Slovakia and Austria (Blank et al. 2010, VÉtek et al. 2010), it has been found in Serbia (Hirka 2010, Glavendekić et al. 2013), Italy (ZAndigiacomo et al. 2011), Germany (Kraus et al. 2011), Croatia (MAtošević 2012), Slovenia (DE Groot et al. 2012) and Bulgaria (Doychev 2015). It was also reported from Moldova as early as 2008 (Timuş et al. 2008), but misidentified as Arge sp. (Blank et al. 2014). Aproceros leucopoda occurs also in the European part of Russia (ArToкHin et al. 2012, Lengesova 2012, Shchurov et al. 2012, Lengesova \& Mishchenko 2013); e.g. in the Rostov Region, the pest was recorded in an area as large as almost 
$30000 \mathrm{~km}^{2}$ in 2011 (ARtokнin et al. 2012). A range extension of the sawfly towards western Europe has been documented by recent reports from Belgium (Boevé 2013, Ravoet 2014), the Netherlands (Mol \& Vonk 2014, 2015), the Czech Republic (JurášKová et al. 2014) and northeastern Germany (Blank et al. 2014). Severe damage up to defoliation of most of the canopy caused by the larvae of A. leucopoda may occur in various elm taxa (BLANK et al. 2010, 2014).

Aproceros leucopoda is supposed to spread both actively and passively. Since the adult sawflies are strong fliers (Wu 2006), their natural expansion may result in new infestations (BLANK et al. 2014). However, the human-mediated dispersal of various developmental stages of the pest as stowaways in road, rail etc. traffic and along corridors, or as contaminants of plants for planting via trade might also contribute to its range expansion (BLANK et al. 2010, Zandigiacomo et al. 2011, Аrtokhin et al. 2012, Shchurov et al. 2012, Glavendekić et al. 2013, Blank et al. 2014, Mol \& Vonk 2014, 2015).

Considering the severe damage the invasive alien A. leucopoda is able to cause to its host plants (Blank et al. 2010, Zandigiacomo et al. 2011, АRтокHIN et al. 2012, ShChurov et al. 2012, VÉTEK et al. 2012, BLANK et al. 2014) and the lack of effective methods of trapping adults of the pest, there is an evident need for tools that could be applied for early detection and population monitoring purposes.

Trapping is a convenient access to obtain large, general samples of Hymenoptera from most habitats. Malaise traps or yellow pan traps are often used, which work continuously contrary to a person collecting with a handnet. Yellow pan traps (as well as yellow sticky traps) work on the principle that many insect species are attracted to the yellow colour (GAULD \& Bolton 1988, ViITASAARI 2002). Yellow sticky traps represent an approach to monitor flight activity, abundance and distribution of sawfly species, which occur as pests (e.g. Digweed et al. 1997, Kessel 2000, Holusa \& Drápela 2003, 2006, Rodeghiero 2006, Holuša \& Lubojacký 2007, Looney et al. 2012), but also of other Hymenoptera species like parasitoids (e.g. Langor et al. 2000). However, for example, adults of the azalea sawfly, Nematus lipovskyi Smith (Tenthredinidae), a recently reported species alien to Europe, were not attracted to either yellow pitfall traps or yellow sticky plates (МАсек \& Ší́িек 2015).

Most literature data about collections of sawflies with the help of yellow sticky traps refer to pest species associated with Tenthredinidae and Pamphiliidae (e.g. Battisti \& Rodeghiero 1998, and the previous references). There is limited information available from faunistic literature about trapping of Argidae with yellow-coloured sticky traps or pan traps (e.g. Perović et al. 2006). CARdaş et al. (2011) applied white and yellow sticky panels to check the flight period of the adults of $A$. leucopoda, a member of Argidae being the subject of this paper, but the quantities have not been mentioned in their paper, which basically focused on Carabidae species occurring in a Romanian hardwood 
forest infested with A. leucopoda. Glavendekić et al. (2013) used yellow sticky traps to catch adults of $A$. leucopoda in a survey, which targeted to obtain data on the occurrence of the pest in Serbia. However, no further data have been presented on either the design or the effectiveness of the traps applied.

The aim of our study has been to test the applicability and to compare the effectiveness of traps of three different colours for catching A. leucopoda.

\section{MATERIAL AND METHODS}

The study was carried out in a mixed forest plantation comprising black locust (Robinia pseudoacacia L.) and Siberian elm (Ulmus pumila L.) located at Kecskemét, Hungary, in 2012. The 15 ha large plantation was established in 1999. Regular and severe defoliation of elms caused by A. leucopoda has been observed since 2011. To carry out the trapping trial, a ca. 0.8 ha large plot close to the southern edge of the forest $\left[46.9899^{\circ} \mathrm{N} 19.6706^{\circ} \mathrm{E}\right]$ was chosen.

Three different colours of the same "cloak" trap type with a sticky surface of $23 \times 36$ cm (Csalomon®, Plant Protection Institute, Centre for Agricultural Research, Hungarian Academy of Sciences, Budapest, Hungary) were tested, hereafter symbolised as PALf (white), PALs (yellow) and PALz (fluorescent yellow) by following the abbreviation of the commercially available trap types. The latter colour was included in the study because it proved more effective than yellow sticky "cloak" traps in the case of Rhagoletis cerasi (L.) (Diptera: Tephritidae), a major pest of cherries (Tótн et al. 2004). The efficiency of fluorescent yellow traps [colour 154 B defined by the Colour chart of the Royal Horticultural Society (1966 cit. van Epenhuijsen \& De Silva 1991)] was confirmed by van Epenhuijsen and DE SIlvva (1991) in a study on trapping Caliroa cerasi (L.) (Tenthredinidae), a pest of stone and pome fruits. On the other hand, Looney et al. (2012) found lime green Asian citrus psyllid sticky traps ineffective compared to yellow sticky traps for detecting the alderfeeding Monsoma pulveratum (Retzius) (Tenthredinidae). Therefore, trials with PALz traps seemed practical. The reflectance spectrum of each of the traps has been recorded previously: white PALf trap (Schmera et al. 2004), yellow PALs and fluorescent yellow PALz traps (Tóтн et al. 2004).

The traps were hanged by wires and fixed to lower branches of trees at a height of 1.5-2.5 m. There were $n=12$ replicates of each colour (note: one PALz was found dropped to the ground, so in this case finally we had $n=11$ replicates). The distance among traps within one block that contained the three different colours was min. $2 \mathrm{~m}$, and the distance among the 12 blocks was min. $9 \mathrm{~m}$. The traps were placed in the field on 19 May 2012, and the numbers of captured A. leucopoda adults were counted on 31 May. This trapping period was set to coincide with the peak of the second emergence of adults at the study site so as to catch as many specimens as possible with the different traps.

To compare the captures of the three coloured traps, random block design one-way ANOVA model was run with fixed factor 'colour' (white, yellow and fluorescent yellow). A single extreme value was winsorized at the 99\% (WiLcox 2005). Normality of residuals was proved by Kolmogorov-Smirnov's test $(\mathrm{D}(35)=0.064 ; \mathrm{p}=0.2)$. Since homogeneity of variances failed, notwithstanding small means occurred with small variances and sample sizes were almost the same, therefore post hoc test was run by Games-Howell's method. We also calculated the eta squared to detect the effect size which gives the explained variance rate as well as the observed power which provides the probability of correct detection of significant differences. 


\section{RESULTS}

Most A. leucopoda adults $(\mathrm{N}=4645)$ were captured with the yellow sticky "cloak" (PALs) traps followed by the fluorescent yellow (PALz) traps (N =3441). The white (PALf) traps were the least attractive $(\mathrm{N}=332)$ to the sawfly species. Mean number $( \pm \mathrm{SD})$ of A. leucopoda adults captured with different sticky "cloak" (PAL) traps is shown in Figure 1. There was no significant difference between the catches of the PALs and PALz traps (Games-Howell's $p=0.534$ ), and both of them proved significantly more effective compared to the PALf traps (GamesHowell's $\mathrm{p}<0.001)$. Significant effect of the colour was proved $\left(F_{2,21}=27.26\right.$, $p<0.001)$. Observed power was as high as 0.999 with eta squared $\eta^{2}=0.60$.

\section{DISCUSSION}

Based on our results, both the yellow and fluorescent yellow sticky "cloak" traps are similarly suitable for catching A. leucopoda adults. Also yellow-coloured traps proved more effective for collecting sawflies compared to different further colours applied in other studies: RüHL (1978) collected ca

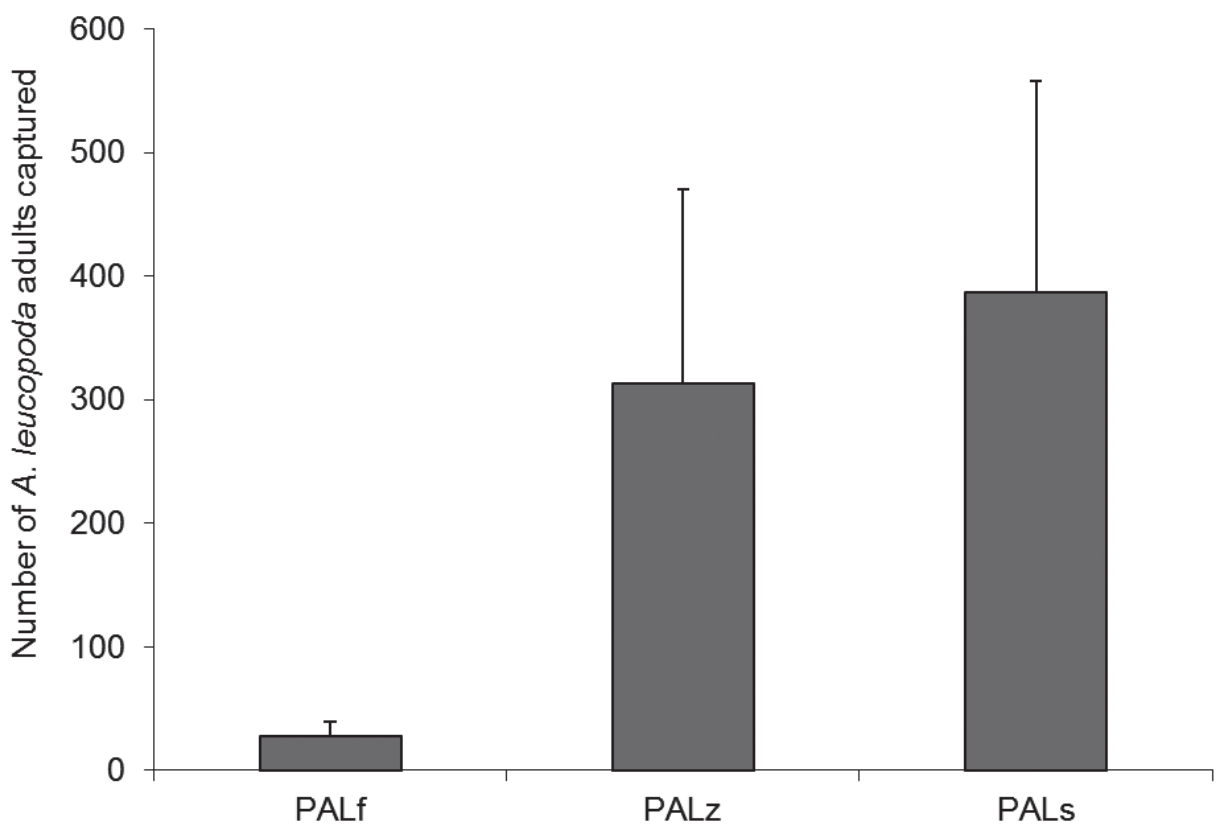

Fig. 1. Mean number $( \pm \mathrm{SD})$ of Aproceros leucopoda adults captured with different Csalomon® sticky "cloak" (PAL) traps in a mixed forest plantation of black locust (Robinia pseudoacacia) and Siberian elm (Ulmus pumila) located at Kecskemét, Hungary, between 19 and 31 May 2012. (PALf - white; PALz - fluorescent yellow; PALs - yellow). 
$81 \%$ of sawflies in yellow, $17 \%$ in white, and 3\% in blue pan traps. In the case of raised bogs studied by Schuster (1985), yellow pan traps were the most attractive collecting $93 \%$ of all the sawflies, while only $5 \%$ and $2 \%$ of the specimens were captured in white and blue traps, respectively. In a study by RITZAU (1988) carried out on the sawfly fauna of two islands of northwestern Germany, 66\% and 34\% were trapped in yellow dishes and in white ones, respectively. Although the preference was dominated by Athalia rosae (L.) (Tenthredinidae) (540 of 863 specimens associated with 32 species), also the exclusion of this species resulted in similar rates for the remaining 323 specimens: $71 \%$ in yellow, and $29 \%$ in white traps.

Even though the white sticky "cloak" traps also captured many specimens in our experiment, they might be less practical for early detection and monitoring of A. leucopoda. Holuša and Drápela (2006) found that white sticky boards were not attractive to Pristiphora abietina (Christ) (Tenthredinidae), and although these traps captured some adults, the authors suggested that this might be a coincidence with the period of peak emergence of the species. Although in the case of Hoplocampa testudinea (Klug) (Tenthredinidae), a pest of apples, Owens and Proкору (1978) experienced that white sticky rectangular traps which do not reflect the UV light captured more $H$. testudinea adults than yellow, red, orange, black, green, and blue enamels, various daylight fluorescent hues, and further surfaces tested, according to the authors, the species might respond to some visual cue supplied by apple blossoms.

The application of Malaise traps might be an alternative method of trapping A. leucopoda as they are suitable for collecting Argidae (BraUd et al. 2003, Roller 2006, Smith 2006, Blank unpubl.). Holuša and Drápela (2006) found that there was a highly significant relationship between samples of Malaise traps and yellow sticky boards in the case of P. abietina (in both sexes in 1998, in males in 1999). Malaise traps, nevertheless, would not be recommended for the detection of $A$. leucopoda for many reasons: they collect a very large amount of insect material, which causes significant effort for sorting; the vast proportion of the collection comprises non-target species, which is unreasonable in view of nature conservation aspects; and due to their showy appearance they are not practical to use in some environments where elms regularly occur: public areas, along roads, in nurseries or private gardens. Furthermore, based on a study of Cephalcia lariciphila (Wachtl) (Pamphiliidae) by HoLušA and Kuras (2010), the authors deemed Malaise traps more expensive and difficult to use in forestry, compared to yellow sticky boards.

Representing non-selective traps, yellow-coloured traps may capture several non-target insect species, including members of Symphyta other than A. leucopoda (see references in the Introduction). However, adults of $A$. leucopoda can readily be distinguished from other West Palaearctic Hymenoptera 
by using the keys and descriptions given by Blank et al. (2010) and Mol and Vonk (2015). Although searching for the easily recognizable zigzag feeding pattern on leaves caused by the young larval stages (BLANK et al. 2010, VÉTEK et al. 2010) may be recommended for e.g. citizen scientists supporting monitoring programs (BLANK et al. 2014), new invasions by the adults to uninfested regions might be signalised with either yellow or fluorescent yellow sticky "cloak" traps (PALs or PALz). Practically, trapping should complement the inspection of the host plants since the two approaches record different development stages of $A$. leucopoda, adults and larvae. These comparatively inconspicuous traps are suitable for application also in environments frequented by people. Besides early detection of the invasive species, phenological data may be recorded as well with both traps, and this may help understand the population dynamics of $A$. leucopoda.

Acknowledgements - The authors would like to thank Dávid Rédei (Institute of Entomology, Nankai University, Tianjin, China) for his kind help in reviewing Chinese literature related to the topic of this article. This paper was supported by the János Bolyai Research Scholarship of the Hungarian Academy of Sciences. The project was partly supported by the COST Action TD1209, European Information System for Alien Species.

\section{REFERENCES}

Artoknin, K. S., Ignatova, P. K. \& Terskov, E. N. (2012) New insects including invasive species for the fauna of Rostov Region (Russia). Caucasian Entomological Bulletin 8(2): 199-202. [in Russian]

Battisti, A. \& Rodeghiero, M. (1998) Monitoring spruce web-spinning sawflies Cephalcia spp.: the correlation between trap catches and soil sampling. Entomologia Experimentalis et Applicata 88: 211-217. http://dx.doi.org/10.1046/j.1570-7458.1998.00365.x

Blank, S. M., Hara, H., Mikulás, J., Csóka, Gy., Ciornei, C., Constantineanu, R., Constantineanu, I., Roller, L., Altenhofer, E., Huflejt, T. \& Vétek, G. (2010) Aproceros leucopoda (Hymenoptera: Argidae): An East Asian pest of elms (Ulmus spp.) invading Europe. European Journal of Entomology 107: 357-367. http://dx.doi.org/10.14411/ eje. 2010.045

Blank, S. M., Köhler, T., Pfannenstill, T., Neuenfeldt, N., Zimmer, B., Jansen, E., Taeger, A. \& Liston, A. D. (2014) Zig-zagging across Central Europe: recent range extension, dispersal speed and larval hosts of Aproceros leucopoda (Hymenoptera, Argidae) in Germany. Journal of Hymenoptera Research 41: 57-74. http://dx.doi.org/10.3897/ JHR.41.8681

Boevé, J.-L. (2013) First record in Belgium of the invasive sawfly Aproceros leucopoda (Hymenoptera: Argidae) and some related ecological data. Bulletin de la Société royale belge d'Entomologie / Bulletin van de Koninklijke Belgische Vereniging voor Entomologie 149(3): 217-221. 
Braud, R., Smith, D. R., Strazanac, J. S. \& Butler, L. (2003) Diversity, abundance, and seasonality of adult and larval Symphyta (Hymenoptera) in the George Washington National Forest, Virginia, and the Monongahela National Forest, West Virginia. Proceedings of the Entomological Society of Washington 105(3): 756-768.

Cardaş, G., LupăşTean, D. \& Baudouin, A. (2011) Prădători din familia Carabidae prezenți în păduri de foioase din partea de est a României, cu ulm în compoziție, infestate cu Aproceros leucopoda Takeuchi (Hymenoptera, Argidae). Pp. 16-21. In: Materialele Simpozionului Internaţional. Dezvoltarea durabilă a sectorului forestier - noi obiective şi priorităţi. Chişinău, 17-19 noiembrie 2011. [in Romanian]

de Groot, M., Hauptman, T. \& Seljak, G. (2012) Prva najdba invazivne brestove grizlice, Aproceros leucopoda (Hymenoptera: Argidae) v Sloveniji. The first record of the invasive »zigzag« sawfly Aproceros leucopoda (Hymenoptera: Argidae) in Slovenia. Gozdarski vestnik 70(1): 3-7. [on Slovanian with an English abstract]

Digweed, S. C., Spence, J. R. \& Langor, D. W. (1997) Exotic birch-leafmining sawflies (Hymenoptera: Tenthredinidae) in Alberta: distributions, seasonal activities, and the potential for competition. The Canadian Entomologist 129: 319-333. http://dx.doi. org/10.4039/Ent129319-2

Doychev, D. (2015) First record of the invasive elm sawfly Aproceros leucopoda Takeuchi (Hymenoptera: Argidae) in Bulgaria. Silva Balcanica 16(1): 108-112.

Gauld, I. \& Bolton, B. (eds) (1988) The Hymenoptera. Oxford University Press, New York, $332 \mathrm{pp}$.

Glavendekić, M., Petrović, J. \& Petaković, M. (2013) Alien invasive species Aproceros leucopoda Takeuchi (Hymenoptera: Argidae) - elm pest in Serbia. Sumarstvo 1-2: 47-56. [in Serbian]

Hirka, A. (ed.) (2010) A 2009. évi biotikus és abiotikus erdógazdasági károk, valamint a 2010-ben várható károsítások. Erdészeti Tudományos Intézet, Mátrafüred, 126 pp.

Holusa, J. \& DrápelA, K. (2003) Integrated management of little spruce sawfly (Pristiphora abietina): design pattern. Pp. 16-24. In: McManus, M. L. \& Liebhold, A. M. (eds): Proceedings. Ecology, survey and management of forest insects. Kraków, Poland, 1-5 September 2002. USDA Forest Service, Northeastern Research Station, General Technical Report NE-311.

Holuša, J. \& Drápela, K. (2006) Yellow sticky boards: a possible way of monitoring little spruce sawfly (Pristiphora abietina) (Hymenoptera: Tenthredinidae). Journal of Forest Science 52(1): 13-21.

Holusa, J. \& Kuras, T. (2010) Diurnal behaviour of Cephalcia lariciphila (Hymenoptera: Pamphiliidae): relation to climatic factors and significance for monitoring. European Journal of Forest Research 129(2): 243-248. http://dx.doi.org/10.1007/s10342-009-0321-3

HolušA, J. \& Luвојаски́, J. (2007) Correlation between flight activity of sawflies Pristiphora abietina, P. saxesenii, P. gerula and P. leucopodia (Hymenoptera: Tenthredinidae) and spruce (Picea abies) bud breaking in Eastern Czech Republic. Journal of Forest Science 53: 69-73.

Juráš́ová, M., Hradil, K. \& Macek, J. (2014) Pilatěnka Aproceros leucopoda - nový invazní škůdce v České Republice. Rostlinolékař 3: 21-23. [in Czech]

Kessel, C. (2000) The impact of the pine false webworm on the Ontario Christmas tree industry. Pp. 33-35. In: Lyons, D. B., Jones, G. C. \& Scarr, T. A. (eds): Proceedings of a workshop on the pine false webworm, Acantholyda erythrocephala (Hymenoptera: Pamphiliidae). University of Toronto, Toronto, Ontario, Canada, 16 February 1998. 
Kraus, M., Liston, A. D. \& Taeger, A. (2011) Die invasive Zick-Zack-Ulmenblattwespe Aproceros leucopoda Takeuchi, 1939 (Hymenoptera: Argidae) in Deutschland. DGaaENachrichten 25(3): 117-119.

Langor, D. W., Digweed, S. C., Williams, D. J. M., Spence, J. R. \& Saunders, C. (2000) Establishment and spread of two introduced parasitoids (Ichneumonidae) of the birch leafminer, Fenusa pusilla (Tenthredinidae). BioControl 45: 415-423. http://dx.doi. org/10.1023/A:1026598305752

Lengesova, N. A. (2012) Elm sawfly (Aproceros leucopoda Takeuchi, 1939) - an elm pest new to the territory of the Ulyanovsk Region. Priroda Simbirskogo Povolzh'ya 13: 136139. [in Russian]

Lengesova, N. A. \& Mishchenko, A. V. (2013) Biology, ecology and molecular characterization of Aproceros leucopoda (Takeuchi, 1939) (Hymnenoptera: Argidae), pest of elms in the Middle Volga region. Caucasian Entomological Bulletin 9 (1): 163-167. [in Russian]

Looney, C., Sheehan, K., Bai, B., Flowers, R., Kohler, G., LaGasa, E., McKorney, A. E. \& Sмiтh, D. R. (2012) The distribution of a potential new forest pest, Monsoma pulveratum (Hymenoptera: Tenthredinidae), in the Pacific Northwest states. Northwest Science 86(4): 342-345. http://dx.doi.org/10.3955/046.086.0409

MAceK, J. \& ŠípeK, P. (2015) Azalea sawfly Nematus lipovskyi (Hymenoptera: Tenthredinidae), a new invasive species in Europe. European Journal of Entomology 112(1): 180186. http://dx.doi.org/10.14411/eje.2015.018

MatošEvić, D. (2012) Prvi Nalaz brijestove ose listarice (Aproceros leucopoda), nove invazivne vrste u Hrvatskoj. First record of elm sawfly (Aproceros leucopoda), new invasive species in Croatia. Šumarski list 136(1-2): 57-61.

Mol, A. \& Vonk, D. (2014) De iepenzigzagbladwesp: een nieuwe exoot in Nederland. http:// www.natuurbericht.nl/?id=12191 [accessed on 09.03.2015]

Mol, A. W. M. \& Vonk, D. H. (2015) De iepenzigzagbladwesp Aproceros leucopoda (Hymenoptera, Argidae), een invasieve exoot in Nederland. Entomologische Berichten 75(2): 50-63.

Owens, E. D. \& Prokopy, R. J. (1978) Visual monitoring trap for European apple sawfly. Journal of Economic Entomology 71: 576-578. http://dx.doi.org/10.1093/jee/71.4.576

Perović, F., Merdić, E. \& Perović, G. (2006) Sawflies (Hymenoptera, Symphyta) in the biotopes of Kopački rit. Natura Croatica 15(4): 189-201.

Ravoet, J. (2014) Iepenzigzagwesp verovert Vlaanderen. http://www.natuurbericht.be/mobi/ mobielbericht.php?id=12844 [accessed on 18.03.2015]

Ritzau, C. (1988) Zur Pflanzenwespenfauna junger Düneninseln der südlichen Nordsee (Hymenoptera: Symphyta). Drosera 1988: 139-153.

Rodeghiero, M. (2006) On the sawfly Pristiphora subarctica (Forsslund, 1936) (Hymenoptera: Tenthredinidae) in spruce plantations of the Southern Alps. Pp. 167-172. In: Blank, S. M., Schmidt, S. \& TAeger, A. (eds): Recent sawfly research: Synthesis and prospects. Goecke \& Evers, Keltern.

Roller, L. (2006) Seasonal flight activity of sawflies (Hymenoptera, Symphyta) in submontane region of the Western Carpathians, Central Slovakia. Biologia, Bratislava 61(2): 193-205. http://dx.doi.org/10.2478/s11756-006-0030-z

RüHL, D. (1978) Untersuchungen an Hymenopteren eines naturnahen Lebensraumes, einer Brachfläche sowie je eines alternativ und konventionell bewirtschafteten Obstgutes (Hymenoptera: Symphyta, Aculeata). Arbeiten aus dem Institut für Landwirtschaftliche Zoologie und Bienenkunde, Bonn, 4: [4] + 220 pp. 
Schmera, D., Tóth, M., Subchev, M., Sredkov, I., Szarukán, I., Jermy, T. \& Szentesi, Á. (2004) Importance of visual and chemical cues in the development of an attractant trap for Epicometis (Tropinota) hirta Poda (Coleoptera: Scarabaeidae). Crop Protection 23: 939-944. http://dx.doi.org/10.1016/j.cropro.2004.02.006

Schuster, B. (1985) Zum Auftreten von Pflanzenwespen in Hochmoorresten des Norddeutschen Flachlandes (Hymenoptera, Symphyta). Drosera 1985: 1-16.

Shchurov, V. I., Gninenko, Yu. I., Lengesova, N. A. \& Gninenko, M. Yu. (2012) Elm sawfly in the European part of Russia. Zashchita i karantin rasteniy 2: 37-39. [in Russian]

Sмiтh, D. R. (2006) List of the sawflies (Hymenoptera: Symphyta) of Virginia. Banisteria 28: 3-23.

Timuş, A., Derjanschi, V. \& Croitoru, N. (2008) Viespea neagră a ulmului (Arge sp.) în Republica Moldova şi dezvoltarea acesteia pe ulmul de câmp - Ulmus minor. Mediul Ambiant 4(40): 35-37. [in Romanian]

Tóth, M., Szarukán, I., Voigt, E. \& KozÁr, F. (2004) Hatékony cseresznyelégy- (Rhagoletis cerasi L., Diptera, Tephritidae) csapda kifejlesztése vizuális és kémiai ingerek figyelembevételével. Növényvédelem 40(4): 229-236. [in Hungarian]

van Epenhuijsen, C. W. \& de Silva, H. N. (1991) Monitoring and control of pear slug (sawfly) in an organic nashi orchard. Proceedings of the NZ Weed and Pest Control Conference 44: 80-85.

VÉTEK, G., Lovas, M. \& CsóKA, Gy. (2012) A kanyargós szillevéldarázs (Aproceros leucopoda) 2011-ben ismert elterjedése és kártétele Magyarországon. P. 86. In: KőMíves, T., Haltrich, A. \& Molnár, J. (eds): Növényvédelmi Tudományos Napok 2012. Budapest, 2012. február 21-22. Magyar Növényvédelmi Társaság, Budapest.

Vétek, G., Mikulás, J., CsóKA, Gy. \& Blank, S. M. (2010) A kanyargós szillevéldarázs (Aproceros leucopoda Takeuchi, 1939) Magyarországon. Növényvédelem 46(11): 519-521. [in Hungarian]

VittasaAri, M. (2002) The Suborder Symphyta of the Hymenoptera. Pp. 11-174. In: VIITASAARI, M. (ed.): Sawflies (Hymenoptera: Symphyta). I. A review of the suborder, the Western Palaearctic taxa of Xyeloidea and Pamphilioidea. Tremex, Helsinki.

Wilcox, R. R. (2005) Winsorized robust measures. Published online: 15 Oct. 2005. http:// dx.doi.org/10.1002/0470013192.bsa713

Wu, X.-Y. (2006) Studies on the biology and control of Aproceros leucopoda. Plant Protection (Beijing) 32(4): 98-100. [in Chinese]

Zandigiacomo, P., Cargnus, E. \& Villani, A. (2011) First record of the invasive sawfly Aproceros leucopoda infesting elms in Italy. Bulletin of Insectology 64(1): 145-149.

Received July 1, 2015, accepted November 13, 2015, published May 6, 2016 


\section{SYNTHESYS I}

\section{Synthesis of systematic resources}
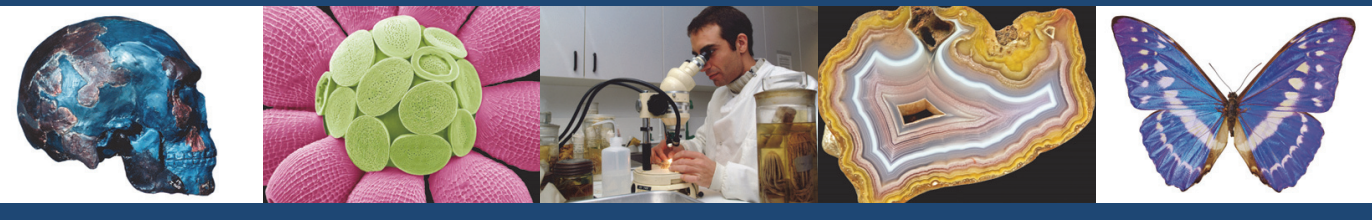

\section{Access to research infrastructures}

SYNTHESYS offers unique research opportunities to scientists from all over Europe. Access is provided to:

- European collections comprising more than half of the world's natural history specimens

- world class libraries

- state-of-the-art facilities including imaging, chemical, and molecular laboratories

- support from in-house scientists, including researchers, facilities staff, and collections managers

Participation is free of charge and is provided on the basis of scientific excellence of a proposal, reviewed by a Selection Panel. Priority is given to new users. A typical project is 1-6 weeks in duration.

The 18 partner institutions offer access via 11 national Taxonomic Access Facilities (TAFs).

AT-TAF: Naturhistorisches Museum, Vienna

BE-TAF: Royal Belgian Institute of Natural Sciences, Brussels; Royal Museum for Central Africa, Tervuren

CZ-TAF: Národni Muzeum, Prague

DE-TAF: Botanischer Garten und Botanisches Museum Berlin-Dahlem, Berlin; Museum für Naturkunde, Berlin; Senckenberg Gesellschaft für Naturforschung, Frankfurt, Dresden, Görlitz and Müncheberg; Staatliches Museum für Naturkunde, Stuttgart
DK-TAF: University of Copenhagen

ES-TAF: Museo Nacional de Ciencias Naturales \& Real Jardín Botánico, Madrid

FR-TAF: Muséum National d'Histoire Naturelle, Paris

GB-TAF: Natural History Museum, London; Royal Botanic Gardens, Kew; Royal Botanic Garden, Edinburgh

HU-TAF: Hungarian Natural History Museum, Budapest

NL-TAF: Naturalis Biodiversity Center, Leiden

SE-TAF: Naturhistoriska riksmuseet, Stockholm

SYNTHESYS will provide finance for:

\section{research costs}

u international travel and accommodation

$\square$ per diem contribution towards living costs

- logistical support at the host institution

Contact SYNTHESYS for details of the online application process and deadlines:

Annual Calls for proposals in October (2013 - 2016)

Visits will be scheduled between January 2014 and August 2017

email: synthesys@nhm.ac.uk

www.synthesys.info

SYNTHESYS is a project supporting an integrated European infrastructure for natural history collections funded via the EC Research Infrastructure Activity, FP7 Programme

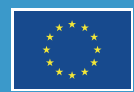

